\title{
IMPLEMENTASI PENGELOLAAN KEUANGAN DESA BERBASIS SISKEUDES DI DESA SRIMULYO KECAMATAN PIYUNGAN KABUPATEN BANTUL
}

\author{
Atik Budi Astuti, Oktiva Anggraini, Retno Kusumawiranti \\ Program Studi Administrasi Publik Universitas Widya Mataram \\ retno_zan@yahoo.co.id
}

\begin{abstract}
The purpose of this study was to determine the implementation of financial management based on Siskeudes in Srimulyo Village, Piyungan District, Bantul Regency. This type of research is a qualitative descriptive study, with data collection techniques including interviews, documentation, and observation. The implementation of village financial management in Srimulyo Village, Piyungan District, Bantul Regency, has paid attention to the principles of village financial management, namely: First, consistency of recording in accordance with the principles of village financial accounting. Second, involve the community in managing village finances. Third, transparency to give the community the right to know information related to village financial management. Fourth, the fulfillment of accountable village financial management. By using the Siskeudes application, village financial management can be implemented in a more informed, effective and efficient manner. However, there are still obstacles related to the Siskeudes application, namely Siskeudes can only be accessed in the village office environment, then when the application is off line and then on line, sometimes some data is lost. Likewise with consolidated reports, district governments still have to compile them manually because the consolidated report format in the Siskeudes cannot be used. District governments should further improve facilitation and assistance as well as training for village governments so that they can be better at managing village finances. The Siskeudes application can be further refined so that data loss does not occur again and the consolidated report format can also be used.
\end{abstract}

Keywords: Implementation, Management, Village Finance, Siskuedes.

\begin{abstract}
Abstraksi
Tujuan penelitian ini adalah untuk mengetahui implementasi pengelolaan keuangan berbasis Siskeudes di Desa Srimulyo Kecamatan Piyungan Kabupaten Bantul. Jenis penelitian ini adalah penelitian deskriptif kualitatif, dengan teknik pengumpulan data meliputi wawancara, dokumentasi, dan observasi. Pelaksanakan pengelolaan keuangan desa di Desa Srimulyo Kecamatan Piyungan Kabupaten Bantul, telah memperhatikan asas-asas pengelolaan keuangan desa yaitu: Pertama, konsistensi pencatatan sesuai dengan prinsip akuntansi keuangan desa. Kedua, melibatkan masyarakat dalan pengelolaan keuangan desa. Ketiga, transparansi untuk memberikan hak kepada masyarakat untuk mengetahui informasi terkait pengelolaan keuangan desa. Keempat, terpenuhinya pengelolaan keuangan desa yang bisa dipertanggungjawabkan. Dengan menggunakan aplikasi Siskeudes maka pengelolaan keuangan desa dapat dilaksanakan dengan lebih tertib, efektif dan efisien. Namun demikian masih ada kendala terkait aplikasi. Siskeudes yaitu Siskeudes hanya bisa diakses di lingkungan kantor desa, kemudian ketika aplikasi off line kemudian di on line maka kadang ada data-data yang hilang. Begitu juga dengan laporan konsolidasi, pemerintah kabupaten masih harus menyusunnya secara manual karena format laporan konsolidasi dalam Siskeudes tidak dapat digunakan. Pemerintah Kabupaten hendaknya lebih meningkatkan fasilitasi dan pendampingan serta pelatihan kepada pemerintah desa agar lebih baik lagi dalam pengelolaan keuangan desa. Aplikasi Siskeudes agar bisa lebih
\end{abstract}


disempurnakan lagi sehingga tidak terjadi lagi data yang hilang dan format laporan konsolidasi juga bisa difungsikan.

Kata kunci: Implementasi, Pengelolaan, Keuangan Desa, Siskuedes.

\section{Pendahuluan}

Sebagaimana isi dari Undang-Undang Nomor 6 Tahun 2014 tentang Desa meletakkan posisi desa sebagai kesatuan masyarakat hukum adat sesuai hak asal usul desa, sehingga otonomi desa diakui dan dihormati dalam sistem pemerintahan Negara Kesatuan Republik Indonesia. Pemerintah desa mempunyai tugas dalam penyelenggaraan pemerintahan desa, pelaksanaan pembangunan desa, pembinaan kemasyarakatan desa, dan pemberdayaan masyarakat desa.

Selaras dengan Program Pembangunan Nasional yang tertuang dalam RPJMD Nasional 2015-2019 yaitu bahwa Pemerintah Indonesia bertekad untuk membangun Indonesia mulai dari pinggiran dengan memperkuat daerah-daerah dan desa dalam kerangka Negara Kesatuan Republik Indonesia. Desa mengatur dan mengurus kepentingan masyarakat setempat dan berperan mewujudkan cita-cita kemerdekaan. Desa menghadapi banyak masalah, antara lain kemiskinan, derajat kesehatan masyarakat yang memprihatinkan, tingkat pendidikan yang rendah, angka pengangguran yang cukup tinggi, rendahnya kapasitas penyelenggara pemerintahan desa, kerusakan lingkungan alam, kerusakan infrastruktur dll. Dengan adanya tambahan pendapatan desa yang signifikan maka persoalan-persoalan tersebut akan terus ditangani dan dicarikan solusinya sesuai dengan prioritas dan kewenangan desa. Apalagi perencanaan, alokasi, pelaksanaan dan pertanggung jawaban penggunaan dana dilaksanakan oleh desa itu sendiri, tentu saja ini merupakan aksi yang nyata untuk pemberdayaan masyarakat.

Di tahun 2015 Kementerian Dalam Negeri melakukan kerja sama dengan Badan Pengawasan Keuangan dan Pembangunan (BPKP) dalam membangun suatu aplikasi sistem pengelolaan keuangan desa secara komputerisasi. Aplikasi tersebut dinamakan dengan Sistem Pengelolaan Keuangan Desa disingkat Siskeudes. Dengan aplikasi keuangan desa ini, diharapkan pemerintah desa dapat mewujudkan tata kelola keuangan desa yang bersih, tertib, efektif dan efisien. Proses pengawasan dan pemeriksaan pertanggungjawaban keuangan desa juga lebih mudah diterapkan.

Kabupaten Bantul terdiri dari 17 Kecamatan dan 75 desa. Jumlah total Dana Desa pada tahun 2019 adalah sebesar Rp. 98.359.905.000,- (Sembilan puluh delapan milyar tiga ratus lima puluh sembilan juta sembilan ratus lima ribu rupiah). Dengan dana sebanyak itu memang desa diberikan kesempatan yang besar untuk mengurus tata pemerintahannya sendiri serta pelaksanaan pembangunan untuk meningkatkan kesejahteraan dan kualitas hidup masyarakat desa. Selain itu pemerintah desa diharapkan untuk lebih mandiri dalam mengelola pemerintahan dan berbagai sumber daya alam yang dimiliki, termasuk di dalamnya pengelolaan keuangan desa dan kekayaan milik desa. Begitu besar peran desa yang diterima desa, tentunya disertai dengan tanggung jawab yang besar pula. Oleh karena itu pemerintah desa harus bisa menerapkan prinsip akuntabilitas dalam tata pemerintahannya, sehingga penyelenggaraan pemerintahan desa harus dapat dipertanggungjawabkan kepada masyarakat sesuai dengan ketentuan yang berlaku.

Masih ada beberapa kendala terkait pengelolaan keuangan desa yang berbasis siskeudes. Berdasarkan penjelasan dari Kasubag Pengelolaan Keuangan Desa pada Bagian Administrasi Pemerintahan Desa Setda Kabupaten Bantul pada tanggal 7 Nopember 2019 menyampaikan bahwa fitur-fitur yang ada dalam siskeudes merupakan hal yang tidak familiar bagi pamong desa. Banyak hal yang berubah dibandingkan dengan metode 
pengelolaan keuangan sebelumnya. Hal tersebut menjadi kesulitan tersendiri bagi desa untuk memahami isi dari aplikasi siskeudes itu sendiri. Selain itu, saat ini belum ada standarisasi barang dan jasa dalam perencanaan anggaran. Hal tersebut mengakibatkan tidak ada keseragaman standar barang dan jasa antara satu desa dengan desa yang lainnya. Ada juga permasalahan terkait nama-nama bidang dan sub bidang yang berbeda antara peraturan perundang-undangan dengan nama-nama bidang dan sub bidang yang ada pada aplikasi siskeudes itu sendiri. Sementara itu masih ada juga permasalahan terkait sumber daya manusia dimana kemampuan dan kecakapan petugas yang berkaitan dalam pengelolaan keuangan desa berbasis siskeudes masih belum sesuai harapan.

Berdasarkan hal-hal di atas maka penulis tertarik untuk meneliti lebih lanjut mengenai implementasi pengelolaan keuangan berbasis siskeudes yang ada di Kabupaten Bantul dengan mengambil sampel di Desa Srimulyo Kecamatan Piyungan Kabupaten Bantul, di mana Desa Srimulyo merupakan salah satu desa yang menerima Dana Desa lebih dari 1.5 milyar rupiah. Dalam pengelolaan dana desa sebesar itu dan diterapkannya aplikasi sikeudes yang mengharuskan pengelola dari desa menguasai teknologi informasi tapi ternyata Desa Srimulyo menghadapi permasalahan masih adanya pamong desa yang kurang menguasai masalah teknologi dan informasi.

Berdasarkan uraian latar belakang diatas, maka permasalahan dapat dirumuskan sebagai berikut: "Bagaimanakah implementasi pengelolaan keuangan berbasis Siskeudes di Desa Srimulyo Kecamatan Piyungan Kabupaten Bantul?". Tujuan dari penelitian ini adalah untuk mengetahui implementasi pengelolaan keuangan berbasis Siskeudes di Desa Srimulyo Kecamatan Piyungan Kabupaten Bantul.

\section{Metode}

Jenis penelitian ini adalah penelitian deskriptif kualitatif. Teknik pengumpulan data meliputi wawancara, dokumentasi, dan observasi. Teknik pengambilan informan pada penelitian ini menggunakan teknik sampling (purpose sampling) berdasarkan tujuan yang telah ditetapkan, yakni terdiri dari: Kasubag Pengelolaan Keuangan Desa pada Bagian Administrasi Pemerintahan Desa Setda Kabupaten Bantul; Staf Bagian Administrasi Pemerintahan Desa Setda Kabupaten Bantul; Kasi Pemerintahan Kecamatan Piyungan; Lurah Desa Srimulyo Kecamatan Piyungan Kabupaten Bantul; Kaur Keuangan Desa Srimulyo Kecamatan Piyungan Kabupaten Bantul; Admin Siskeudes Desa Srimulyo Kecamatan Piyungan Kabupaten Bantul; Badan Permusyawaratan Desa dan wakil dari masyarakat.

\section{Hasil dan Pembahasan}

Desa Srimulyo termasuk salah satu desa yang berada di paling timur Kabupaten Bantul yang berbatasan dengan Kabupaten Gunungkidul. Desa Srimulyo memiliki luasan terbesar di Kabupaten Bantul, yakni $\pm 1.462,33$ hektar yang terbagi menjadi 22 pedukuhan. Sebelum diundangkan Peraturan Menteri Dalam Negeri Republik Indonesia Nomor 2 Tahun 2017 tentang Standar Pelayanan Minimal Desa, Pemerintah Desa Srimulyo telah berinisiatif untuk melakukan terobosan dalam bidang pelayanan di desa sehingga pelayanan terasa dekat, terbuka, mudah dan efektif, diantaranya:

a. Mempertegas jam pelayanan tepat pukul 08.00-16.00.

b. Pelayanan Ekstra tiap Sabtu (09.00-12.00) khusus administrasi pertanahan

c. Sistem Pelayanan Satu Pintu. 
d. Menyusun Standar Operasional Prosedur (SOP) terkait Pelayanan

e. Membuat Sistem Antrian Digital

f. Pelayanan dilakukan dengan SID sehingga sangat cepat bahkan dengan jargon "3 M3NIT BERES!"

g. Terdapat Play Ground - Pojok Bermain Anak

h. Terdapat Ruang Laktasi- Pojok Menyusui

i. Memiliki layanan online e-LASTRI (e-Layanan Administrasi Tanpa Antri)

E-Layanan Administrasi Tanpa Antri atau e-LASTRI adalah kemudahan pelayanan administrasi desa yang diberikan kepada warga masyarakat tanpa harus hadir berdesakdesakan di desa. Masyarakat cukup mengirim capture foto dokumen pendukung dan dikirimkan ke call center desa (08132 6666 021). Apabila persuratan sudah siap, operator akan memberikan konfirmasi pengambilan kepada masyarakat yang bersangkutan untuk mengambil dokumen tersebut dengan menunjukkan dokumen asli.

j. Memiliki layanan pengaduan e-SAMBAT (e-Saluran Aspirasi Berbasis Teknologi Informasi)

E-SAMBAT adalah layanan portal pengaduan dan informasi yang disediakan oleh Pemerintah Desa Srimulyo bagi warga masyarakat yang ingin memberikan laporan, pengaduan, saran dan kritik terkait segala hal yang terjadi di lingkungannya. Layanan ini tersedia dalam bentuk aplikasi berbasis android yang dapat didownload di Google Play Store.

Selain melalui aplikasi e-SAMBAT, pengaduan dapat dilakukan pula melalui media-media sebagai berikut:

1) SMS/WA/Telepon di Call Center 081326666021

2) Kotak surat di depan ruang pelayanan

3) Email desa.srimulyo@bantulkab.go.id

4) Kolom komentar di website srimulyo-bantul.desa.id atau srimulyo.bantulkab.go.id

Keuangan desa penting sebagai penopang pembiayaan pencapaian tujuan pembangunan desa. Menurut Peraturan Bupati Nomor 82 Tahun 2019 tentang Pengelolaan Keuangan Desa disebutkan bahwa Keuangan Desa adalah semua hak dan kewajiban desa yang dapat dinilai dengan uang serta segala sesuatu berupa uang dan barang yang berhubungan dengan pelaksanaan hak dan kewajiban desa. Implementasi pengelolaan keuangan desa berbasis Siskeudes di Desa Srimulyo Kecamatan Piyungan Kabupaten Bantul dapat dilihat dalam beberapa indikator yang digunakan dalam penelitian, yaitu :

\section{A. Terselenggaranya pengelolaan keuangan desa sesuai dengan tahapan yang ditentukan.}

Pengelolaan keuangan desa, dikelola dalam masa 1 tahun anggaran yakni mulai tanggal 1 Januari sampai dengan tanggal 31 Desember. Pengelolaan keuangan desa dilakukan dengan Basis Kas di mana pencatatan transaksi pada saat kas diterima atau dikeluarkan dari rekening kas desa. Secara lebih jelas maka tahapan pengelolaan keuangan desa adalah sebagai berikut:

\section{Perencanaan Keuangan Desa}

Perencanaan pengelolaan keuangan Desa merupakan perencanaan penerimaan dan pengeluaran pemerintahan Desa pada tahun anggaran berkenaan yang dianggarkan dalam APBDesa. Di Desa Srimulyo Kabupaten Bantul, Carik Desa mengkoordinasikan penyusunan rancangan APBDesa berdasarkan Rencana Kerja Pemerintah Desa (RKPD) 
tahun berkenaan., sebagai bahan penyusunan rancangan peraturan desa tentang APBDesa. Selanjutnya disampaikan ke lurah desa dan lurah desa menyampaikan ke BPD paling lambat bulan Oktober sebelum tahun anggaran berjalan untuk dibahas bersama dalam musyawarah BPD. Kesepakatan bersama antara lurah desa dan BPD paling lambat bulan Nopember sebelum tahun anggaran berjalan. Sedang penetapan dan pengundangannya dalam peraturan desa tentang APBDesa paling lambat tanggal 31 Desember sebelum tahun anggaran berjalan.

Apabila Desa terlambat dalam menyampaikan rancangan Peraturan Desa tentang APBDesa, Camat tetap melakukan evaluasi Rancangan Peraturan Desa tentang APB Desa sesuai ketentuan peraturan perundang undangan. Berdasarkan kesepakatan bersama Lurah Desa dan BPD, Lurah Desa menyiapkan Rancangan Peraturan Lurah Desa mengenai penjabaran APBDesa. Camat dapat mengundang Lurah Desa dan/atau aparat Desa terkait dalam pelaksanaan evaluasi. Dalam melaksanakan evaluasi rancangan Peraturan Desa tentang APB Desa, Camat membentuk Tim Evaluasi yang ditetapkan dengan Keputusan Camat. Perubahan APB Desa hanya dapat dilakukan 1 (satu) kali dalam 1 (satu) tahun anggaran, kecuali dalam keadaan luar biasa dan ditetapkan dengan Peraturan Desa mengenai perubahan APB Desa dengan tetap mempedomani RKP Desa.

Keputusan Badan Permusyawaratan Desa (BPD) Desa Srimulyo tentang Persetujuan Rancangan Peraturan Desa tentang Anggaran Pendapatan dan Belanja Desa Tahun 2019 menjadi Peraturan Desa adalah seperti gambar di bawah ini:

Gambar 3.2 Kesepakatan BPD dengan Pemerintah Desa

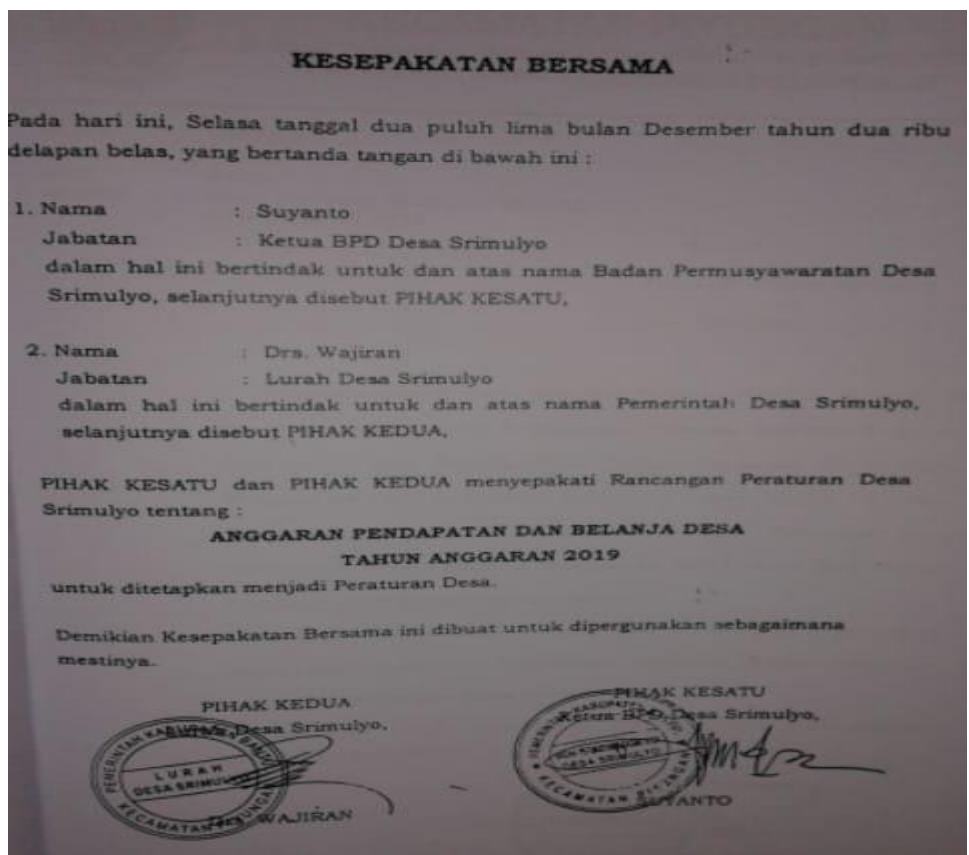

Sumber: Dokumen Pemerintah Desa Srimulyo, 2019

Peraturan Lurah Desa tentang Penjabaran Anggaran Pendapatan dan Belanja Desa Tahun 2019 adalah seperti berikut: 
Gambar 3.3 Peraturan Desa tentang Penjabaran APBDesa

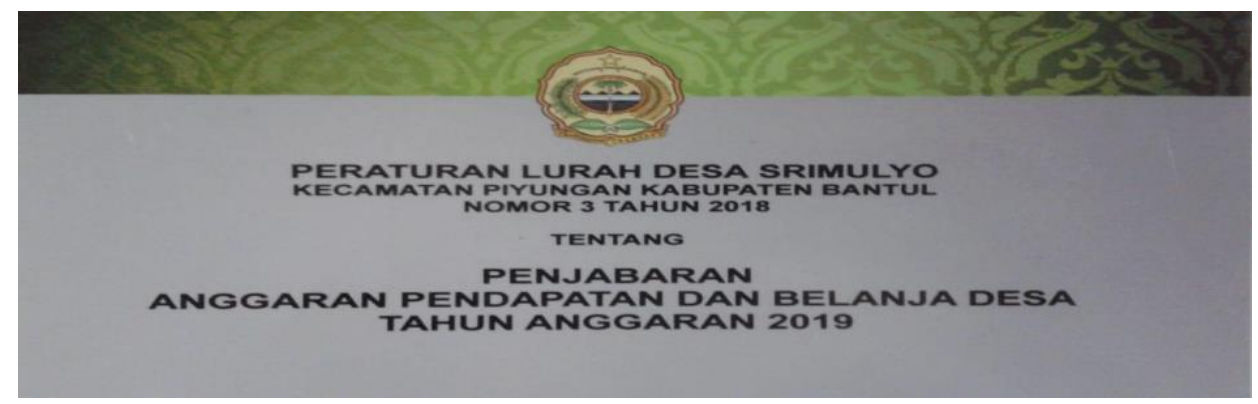

Sumber: Dokumen Pemerintah Desa Srimulyo, 2019

Lurah Desa Srimulyo sudah menyusun Peraturan Desa Srimulyo Nomor 3 Tahun 2018 tentang Penjabaran Anggaran Pendapatan dan Belanja Desa Tahun 2019, tanggal 20 Desember 2019 dan Peraturan Desa Srimulyo Nomor 6 Tahun 2018 tentang Anggaran Pendapatan dan Belanja Desa Tahun 2019 tertanggal 29 Desember 2019 dan juga Rencana Kerja Pemerintah Desa serta telah menyusun Anggaran Pendapatan dan Belanja Desa (APB Desa) Perubahan tahun 2019. Semuanya sudah sesuai dengan peraturan perundang-undangan yang berlaku.

\section{Pelaksanaan Keuangan Desa}

Pelaksanaan pengelolaan keuangan Desa merupakan penerimaan dan pengeluaran Desa yang dilaksanakan melalui rekening kas Desa pada bank yang ditunjuk dengan Keputusan Lurah Desa, dengan spesimen tanda tangan Lurah Desa dan Kepala Urusan Keuangan. Nomor rekening kas Desa dilaporkan Lurah Desa kepada Bupati melalui Camat. Bupati melaporkan daftar nomor rekening kas Desa kepada Gubernur dengan tembusan Menteri Dalam Negeri melalui Direktur Jenderal Bina Pemerintahan Desa, yang nantinya digunakan untuk pengendalian penyaluran dana transfer.

Lurah Desa menugaskan Kepala Urusan dan Kepala Seksi pelaksana kegiatan anggaran sesuai tugasnya menyusun DPA paling lama 3 (tiga) hari kerja setelah Peraturan Desa tentang APBDesa dan Peraturan Lurah Desa tentang Penjabaran APBDesa diundangkan. Dokumen Pelaksanaan Anggaran (DPA) sebagaimana dimaksud terdiri atas:

a. Rencana Kegiatan dan Anggaran Desa, merinci setiap kegiatan, anggaran yang disediakan, dan rencana penarikan dana untuk kegiatan yang telah dianggarkan.

b. Rencana Kerja Kegiatan Desa, merinci lokasi, volume, biaya, sasaran, waktu pelaksanaan kegiatan, pelaksana kegiatan anggaran, dan tim yang melaksanakan kegiatan; dan

c. Rencana Anggaran Biaya, merinci satuan harga untuk setiap kegiatan. 
Pelaksanaan kegiatan dilakukan dengan pengadaan melalui swakelola dan/atau penyedia barang/jasa, namun diutamakan melalui swakelola. Arus kas masuk dan arus kas keluar dari mekanisme pembiayaan dianggarkan dalam APBDesa. Arus kas masuk memuat semua pendapatan Desa yang berasal dari Pendapatan Asli Desa, transfer dan pendapatan lain. Setiap pendapatan didukung oleh bukti yang lengkap dan sah. Arus kas keluar memuat semua pengeluaran belanja atas beban APB Desa. Setiap pengeluaran harus didukung dengan bukti yang lengkap dan sah dan mendapat persetujuan Lurah Desa. Penerimaan pembiayaan dari SiLPA tahun sebelumnya digunakan untuk menutupi defisit anggaran apabila realisasi pendapatan lebih kecil daripada realisasi belanja dan untuk mendanai kegiatan yang belum selesai atau lanjutan.

Kepala Urusan dan Kepala Seksi pelaksana kegiatan anggaran mengajukan kembali rancangan DPA untuk disetujui Lurah Desa menjadi Dokumen Pelaksanaan Anggaran Lanjutan (DPAL) untuk mendanai kegiatan yang belum selesai atau lanjutan. Pelaksana kegiatan anggaran dalam mengajukan rancangan DPAL, terlebih dahulu menyampaikan laporan akhir realisasi pelaksanaan kegiatan dan anggaran kepada Lurah Desa paling lambat tanggal 15 Desember tahun anggaran berjalan. Carik Desa menguji kesesuaian jumlah anggaran dan sisa kegiatan yang akan disahkan dalam DPAL.

Pencairan dana cadangan dan pembentukan dana cadangan dicatatkan dalam Catatan atas Laporan Keuangan (CaLk). Pencatatan pencairan dana cadangan merupakan penyisihan anggaran dana cadangan dalam rekening kas Desa. Pembentukan Dana Cadangan dilarang digunakan untuk membiayai program dan kegiatan lain diluar yang telah ditetapkan dalam Peraturan Desa mengenai dana cadangan dan program dan kegiatan yang ditetapkan berdasarkan Peraturan Desa dilaksanakan apabila dana cadangan telah mencukupi untuk melaksanakan program dan kegiatan. Penyertaan modal dicatat pada pengeluaran pembiayaan dan hasil keuntungan dari penyertaan modal dimasukan sebagai Pendapatan Asli Desa Srimulyo.

Kepala Urusan dan Kepala Seksi pelaksana kegiatan anggaran mengajukan SPP dalam setiap pelaksanaan kegiatan anggaran sesuai dengan periode yang tercantum dalam DPA dengan nominal sama besar atau kurang dari yang tertera dalam DPA. Setiap Pengajuan SPP maka wajib menyertakan laporan perkembangan pelaksanaan kegiatan dan anggaran.

SPP yang sudah dibuat oleh pemerintah desa dibuatkan register sebagaimana contoh dalam gambar berikut:

Gambar 3.6 Register Surat Permintaan Pembayaran (SPP)

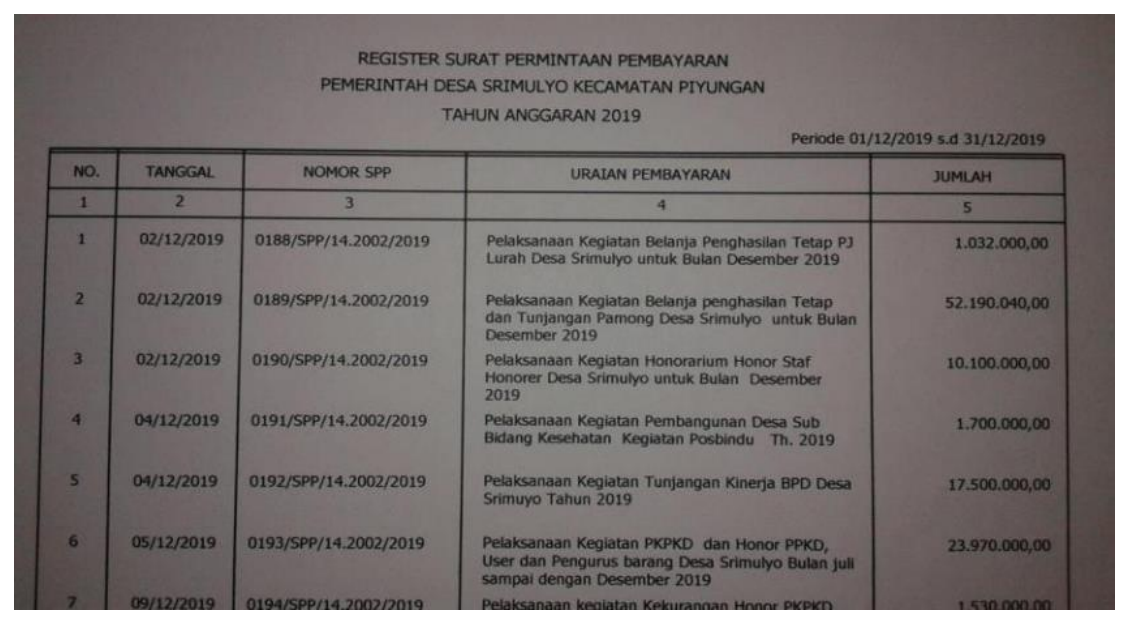

Sumber: Dokumen Pemerintah Desa Srimulyo, 2019 
Pemerintah Desa Srimulyo dalam hal ini sudah melaksanakan penyusunan Dokumen Pelaksanaan Anggaran yang merupakan bagian dari APBDesa, dan dalam penggunaan anggaran sudah melalui proses pengajuan SPP terlebih dahulu untuk pencairan anggaran kemudian setelah pencairan dana baru dilaksanakan oleh pelaksana kegiatan yaitu kepala urusan dan kepala seksi. Dalam pelaksanaan kegiatan pun juga sudah dilakukan pemungutan pajak sesuai dengan ketentuan.

\section{Penatausahaan Keuangan Desa}

Penatausahaan keuangan dilakukan oleh Kepala Urusan Keuangan sebagai pelaksana fungsi kebendaharaan dengan mencatat setiap penerimaan dan pengeluaran dalam buku kas umum. Pencataan pada buku kas umum ditutup setiap akhir bulan. Dalam penatausahaan penerimaan desa, semua Penerimaan Desa dalam rangka pelaksanaan kewenangan desa disetor ke dalam rekening kas desa, dilakukan dengan cara disetor secara langsung ke rekening kas desa oleh pihak ketiga, disetor melalui Kepala Urusan Keuangan oleh pihak ketiga, atau disetor melalui Kepala Urusan Keuangan dari aparat yang bertanggungjawab memungut dari pihak ketiga. Kepala Urusan Keuangan yang menampung sementara penerimaan desa wajib menyetorkan ke rekening kas desa paling lama 1 (satu) hari kerja setelah diterimanya uang. Pemerintah Desa dilarang melakukan pungutan desa sebagai penerimaan desa selain yang ditetapkan dalam Peraturan Desa. Kepala Urusan Keuangan dalam melaksanakan penatausahaan penerimaan desa didukung dengan bukti yang lengkap dan sah antara lain Tanda Bukti Penerimaan (TBP), Surat Tanda Setoran (STS), Bukti Penerimaan lainnya yang sah. Kepala Urusan Keuangan wajib mempertanggungjawabkan penerimaan desa melalui laporan pertanggungjawaban.

Penatausahaan pengeluaran Desa yang mengakibatkan beban APB Desa, dilakukan berdasarkan RAK Desa yang telah disetujui oleh Lurah Desa. Pengeluaran atas beban APBDesa untuk kegiatan yang dilakukan secara swakelola dikeluarkan oleh Kepala Urusan Keuangan kepada Kepala Urusan dan Kepala Seksi pelaksana kegiatan anggaran atas dasar DPA dan SPP yang diajukan serta telah disetujui oleh Lurah Desa. Sementara pengeluaran atas beban APBDesa untuk kegiatan yang dilakukan melalui penyedia barang/jasa dikeluarkan oleh Kepala Urusan Keuangan langsung kepada penyedia atas dasar DPA dan SPP yang diajukan oleh Kepala Seksi pelaksana kegiatan anggaran dan telah disetujui oleh Lurah Desa.

Pemerintah Desa Srimulyo dalam pelaksanaan kegiatannya sudah berdasarkan dengan DPA Desa. Kaur Keuangan juga sudah menyusun Buku Kas Umum dilengkapi dengan Buku Pembantu Bank, Buku Pembantu Pajak dan Buku Pembantu Panjar. Buku Kas Umum ditutup setiap akhir bulan. Buku Kas Umum sebagaiman dimaksud adalah seperti dalam gambar berikut:

Gambar 3.7 Buku Kas Umum

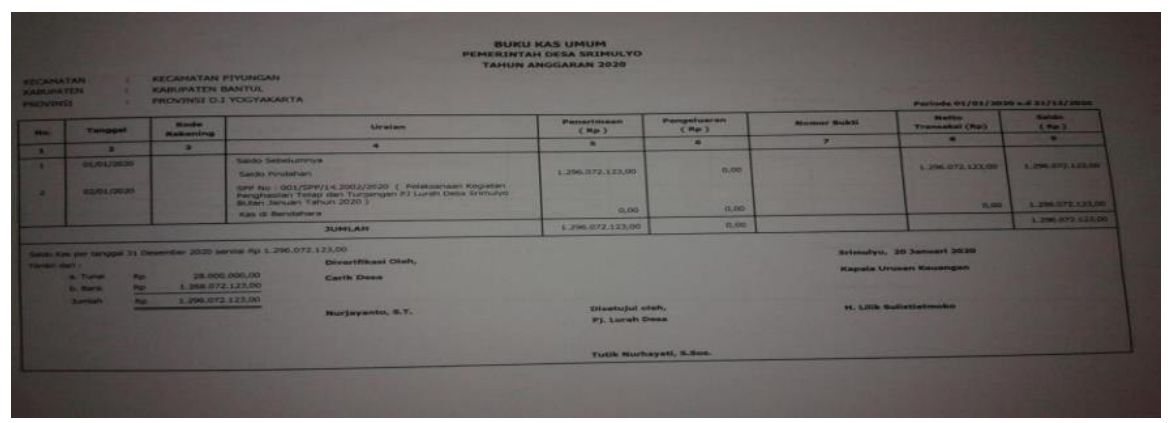

Sumber: Dokumentasi Pemerintah Desa Srimulyo, 2019 
Dengan aplikasi Siskeudes maka penyusunan laporan dan Buku Pembantu menjadi lebih mudah dan lebih tertib karena sudah masuk dalam aplikasi dan tidak lagi dibuat secara manual seperti sebelumnya.

\section{Pelaporan Keuangan Desa}

Lurah Desa menyampaikan laporan pelaksanaan APBDesa kepada Bupati melalui Camat. Pemerintah Desa Srimulyo sudah mengirimkan Laporan Pelaksanaan APBDesa dengan bukti Surat Pengantar dan Laporan seperti di bawah ini:

Gambar 3.9 Laporan Pelaksanaan APBDesa Tahun 2019

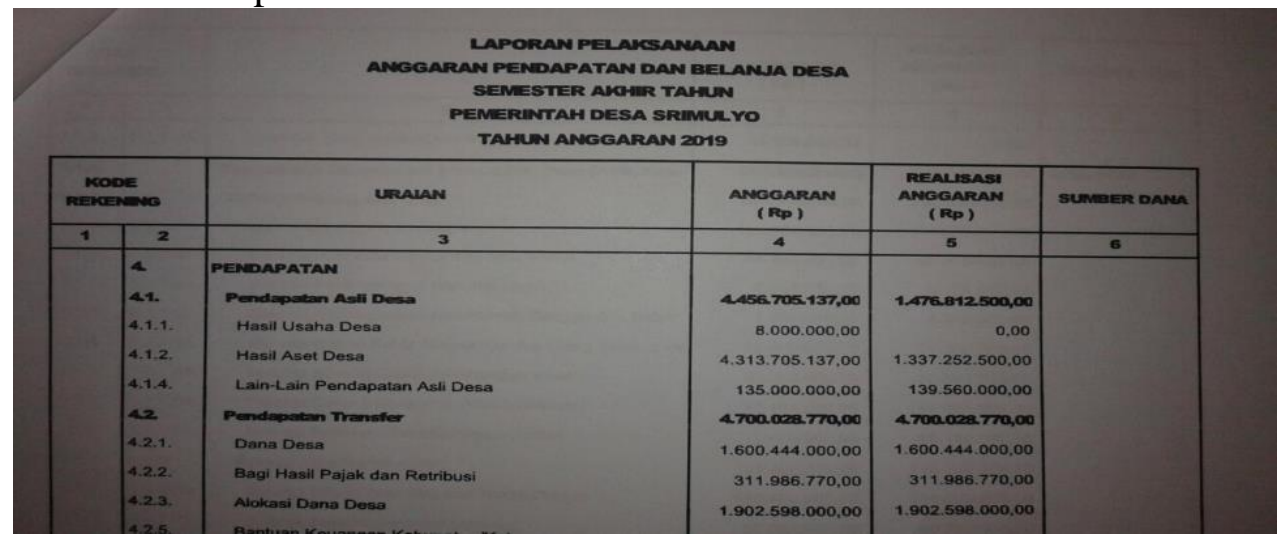

Sumber: Dokumentasi Pemerintah Kabupaten Bantul, 2019

Gambar 3.10 Surat Pengantar Pengiriman Laporan Pelaksananaan APBDesa

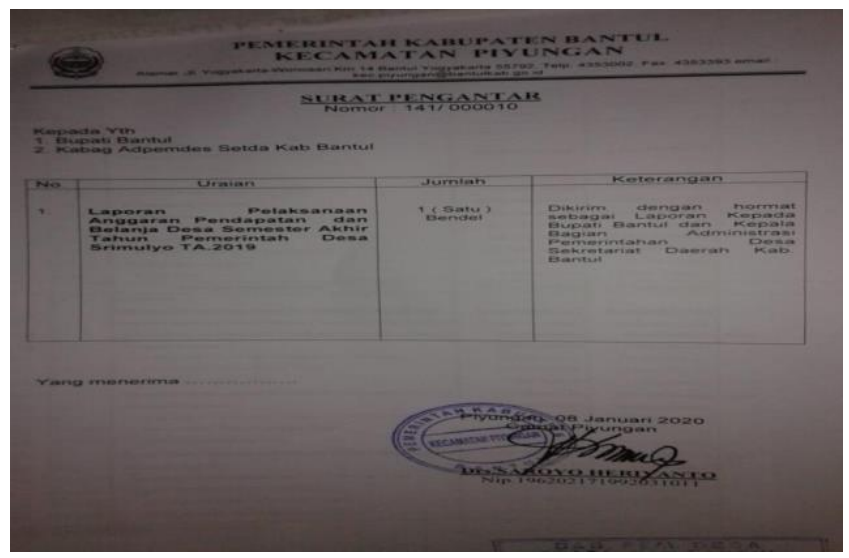

Sumber: Dokumentasi Pemerintah Kabupaten Bantul, 2019

Lurah Desa sudah menyusun laporan pelaksanaan APBDesa dan Laporan Pelaksanaan APBDes Tahun 2019, dikirimkan kepada Bupati Bantul melalui Camat Piyungan dengan Nomor Surat Pengantar 141/00010 tertanggal 08 Januari 2020. Selanjutnya Bupati menyampaikan laporan konsolidasi pelaksanaan APBDesa kepada Menteri Dalam Negeri melalui Direktur Jenderal Bina Pemerintahan Desa. Akan tetapi terkait laporan konsolidasi dalam aplikasi Siskeudes tidak dapat digunakan sehingga harus membuat laporan konsolidasi secara manual akibatnya menghabiskan waktu lebih banyak lagi untuk menyelesaikannya. Harapan ke depannya pihak dari BPKB bisa melakukan penyempurnaan lagi untuk aplikasi Siskeudes ini sehingga bisa difungsikan semaksimal mungkin. 


\section{Pertanggungjawaban Keuangan Desa}

Lurah Desa menyampaikan laporan pertanggungjawaban realisasi APBDesa kepada Bupati melalui Camat setiap akhir tahun anggaran. Laporan pertanggungjawaban dimaksud disampaikan paling lambat 3 (tiga) bulan setelah akhir tahun anggaran berkenaan dan ditetapkan dengan Peraturan Desa. Adapun Peraturan Desa disertai dengan: a). laporan keuangan, terdiri atas laporan realisasi APBDesa dan Catatan Atas Laporan Keuangan; b). laporan realisasi kegiatan; dan d). daftar program sektoral, program daerah dan program lainnya yang masuk ke desa. Laporan pengelolaan keuangan desa untuk selanjutnya diinformasikan kepada masyarakat melalui media informasi paling sedikit memuat: a). laporan realisasi APB Desa; b). laporan realisasi kegiatan; c). kegiatan yang belum selesai dan/atau tidak terlaksana; d). sisa anggaran; dan e). alamat pengaduan.

Lurah Desa Srimulyo sudah menyusun Laporan Realisasi Kegiatan dan Laporan Realisasi APBDesa. Semua kegiatan sudah selesai sesuai dengan Anggaran Pendapatan dan Belanja Desa. Adapun terkait Laporan Penyelenggaraan Pemerintahan Desa (LPPD) masih dalam tahap penyusunan dan belum selesai, karena sesuai dengan peraturan perundang-undangan Laporan Penyelenggaraan Pemerintahan Desa (LPPD) memang paling lambat dikirimkan pada akhir Maret tahun anggaran berikutnya.

\section{B. Konsistensi pencatatan sesuai dengan prinsip akuntansi keuangan desa}

Pengelolaan keuangan desa mengutamakan kepatuhan dan kesesuaian peraturan perundangan. Pengelolaan keuangan juga dilakukan secara berkelanjutan. Pengelolaan keuangan desa harus sesuai dengan peraturan perundang-undangan yang berlaku. APBDesa merupakan dasar pengelolaan keuangan desa dalam masa 1 (satu) tahun anggaran yang dimulai tanggal 1 Januari sampai dengan tanggal 31 Desember. Hal tersebut sesuai dengan apa yang disampaikan oleh Kasubag Pengelolaan Keuangan Desa yang menyampaikan bahwa:

"Pemerintah Desa harus sudah menyelesaikan penyusunan APBDesa pada tanggal 1 Januari tahun yang bersangkutan. Maka kemarin ketika tanggal 31 Desember pukul 24.00 WIB aplikasi Siskeudes kita kunci dan admin tidak bisa entry data lagi. Berbeda dengan dulu ketika belum menggunakan aplikasi Siskeudes, pemerintah desa sering kali terlambat dalam penyusunan APBDesa. Dengan aplikasi ini diharapkan proses pengelolaan keuangan desa mulai dari tahap perencanaan, penatausahaan, pelaksanaan, pelaporan dan pertanggungjawaban, semua menjadi lebih mudah dan lebih tertib". (wawancara tanggal 21 Desember 2019).

Pemerintah Desa Srimulyo sudah menyelesaikan penyusunan APBDesa dan entri data terkait program kegiatan pemerintah desa Srimulyo di dalam aplikasi Siskeudes pada tanggal 1 Januari 2019. Hal tersebut dibuktikan dengan disahkannya Peraturan Desa Srimulyo Nomor 6 Tahun 2018 tentang Anggaran Pendapatan dan Belanja Desa Tahun 2019, tanggal 20 Desember 2018.

\section{Pelibatan masyarakat dalam pengelolaan keuangan desa}

Pelaksanaan pengelolaan keuangan desa, tidak hanya tanggung jawab pemerintah desa semata, melainkan menjadi tanggung jawab seluruh masyarakat. Adapun tugas masyarakat mengawasi pengelolaan keuangan desa secara aktif. baik secara langsung maupun tidak langsung melalui lembaga perwakilan yang dapat menyalurkan aspirasinya dalam hal ini Badan Permusyawaratan Desa. Pemerintah Desa Srimulyo sudah melaksanakan musyawarah desa sebagai ajang untuk menjaring aspirasi masyarakat dalam penyusunan program kegiatan pemerintah desa pada hari Senin tanggal 30 
September 2019 bertempat di Aula Balai Desa Srimulyo Kecamatan Piyungan Kabupaten Bantul, dengan Surat Undangan Nomor 973/168 tertanggal 26 September 2019. Diundang dalam kegiatan tersebut adalah pamong desa, wakil dari tokoh-tokoh masyarakat, Lembaga Kemasyarakatan Desa, dan unsur dari Kecamatan. Sebagaimana disampaikan oleh Kepala Urusan Keuangan Desa Srimulyo, yakni:

"Benar sekali bahwa masyarakat dilibatkan dalam pengelolaan keuangan di desa. Mulai dari musyawarah dusun, musyawarah desa, kita selalu melibatkan serta mengundang tokoh-tokoh masyarakat, dan dari unsur lembaga kemasyarakatan desa yaitu LPMD, Karang taruna dan rukun tetangga. Kalau musyawarah desa yang mempunyai kewenangan untuk melaksanakan adalah Badan Permusyawaratan Rakyat".

Pelaksanaan pengelolaan keuangan desa, melibatkan masyarakat dan para pemangku kepentingan di desa, khususnya kelompok miskin dan marginal sebagai penerima manfaat dari program/kegiatan pembangunan di desa. Oleh karena itu berbagai program kegiatan yang masuk dalam penggunaan dana desa sesuai dengan usulan/kebutuhan masyarakat.

\section{Terpenuhinya transparansi pengelolaan keuangan desa}

Transparansi adalah asas yang membuka diri terhadap hak masyarakat untuk memperoleh informasi yang benar, jujur, dan tidak diskriminatif tentang pengelolaan keuangan desa dalam setiap tahapannya, baik dalam perencanaan dan penganggaran, pelaksanaan anggaran, pertanggungjawaban. asas transparansi menjamin hak semua pihak untuk mengetahui seluruh proses dalam setiap tahapan serta menjamin akses semua pihak terhadap informasi terkait Pengelolaan Keuangan Desa. Pemerintah Desa Srimulyo pro aktif dan memberikan kemudahan bagi masyarakat maupun lembaga masyarakat desa tersebut dapat mengakses/mendapatkan/ mengetahui informasi tentang Pengelolaan Keuangan Desa oleh aparatur desa. Hendro Budi Nugroho, Staf Desa Srimulyo yang mengatakan bahwa:

"Pengelolaan Keuangan Desa di Desa Srimulyo sudah dilaksanakan secara transparan. Anggaran Pendapatan dan Belanja Desa dapat dilihat oleh semua unsur masyarakat dan lembaga masyarakat yang ada di Desa Srimulyo. Rincian APBDesa dapat dilihat di website resmi desa di https://srimulyobantul.desa.id dimana disitu ditampilkan rincian pendapatan dan belanja desa serta pembiayaan sampai ke rincian anggarannya. Ada juga informasi-informasi terkait pelaksanaan kegiatan yang ada di desa. Laporan realisasi anggaran di akhir tahun anggaran pun juga ditampilkan di laman website tersebut. Selain itu ada juga pengumuman tentang APBDesa di baliho di depan balai desa Srimulyo dengan ukuran yang besar dan jelas terlihat". (wawancara tanggal 18 Desember 2019)

Selain hal tersebut di atas, transparansi Pengelolaan Keuangan Desa di Desa Srimulyo juga bisa dilihat melalui aplikasi Sistem Keuangan Desa (Siskeudes). Adapun tampilan aplikasi Sistem Keuangan Desa (Siskeudes) Desa Srimulyo Kecamatan Piyungan adalah seperti gambar di bawah ini: 
Gambar 1. Tampilan Aplikasi Siskeudes Desa Srimulyo

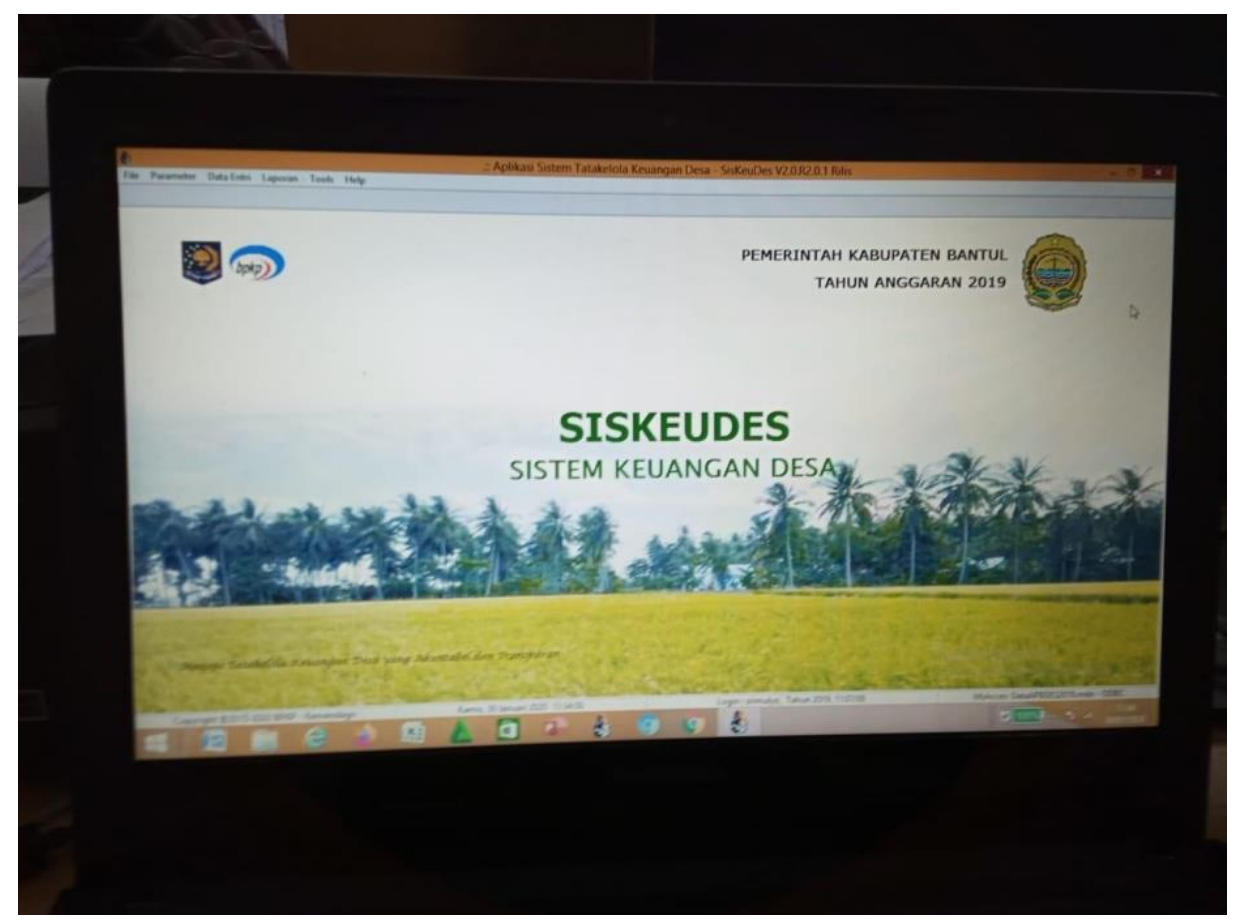

Sumber: Dokumentasi hasil penelitian dan observasi, 2019

Gambar 2. Tampilan Website Desa Srimulyo

○ srimulyo-bantul.desa.id/index.php/first/artikel/510

(3) :

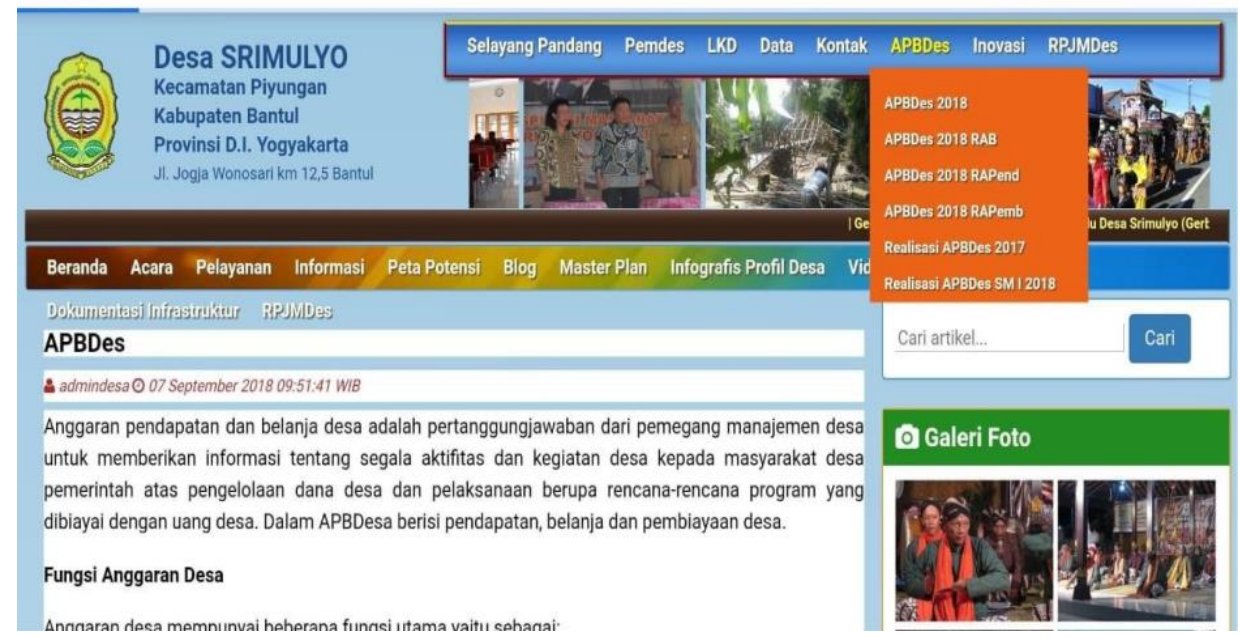

Sumber: website https://srimulyo-bantul.desa.id

Sementara baliho besar yang memuat program kegiatan dalam APBDesa tahun 2019, yang dipasang di depan kantor desa Srimulyo adalah sebagai berikut: 
Gambar 3 Baliho Pengumuman Program Kegiatan Pemerintah Desa

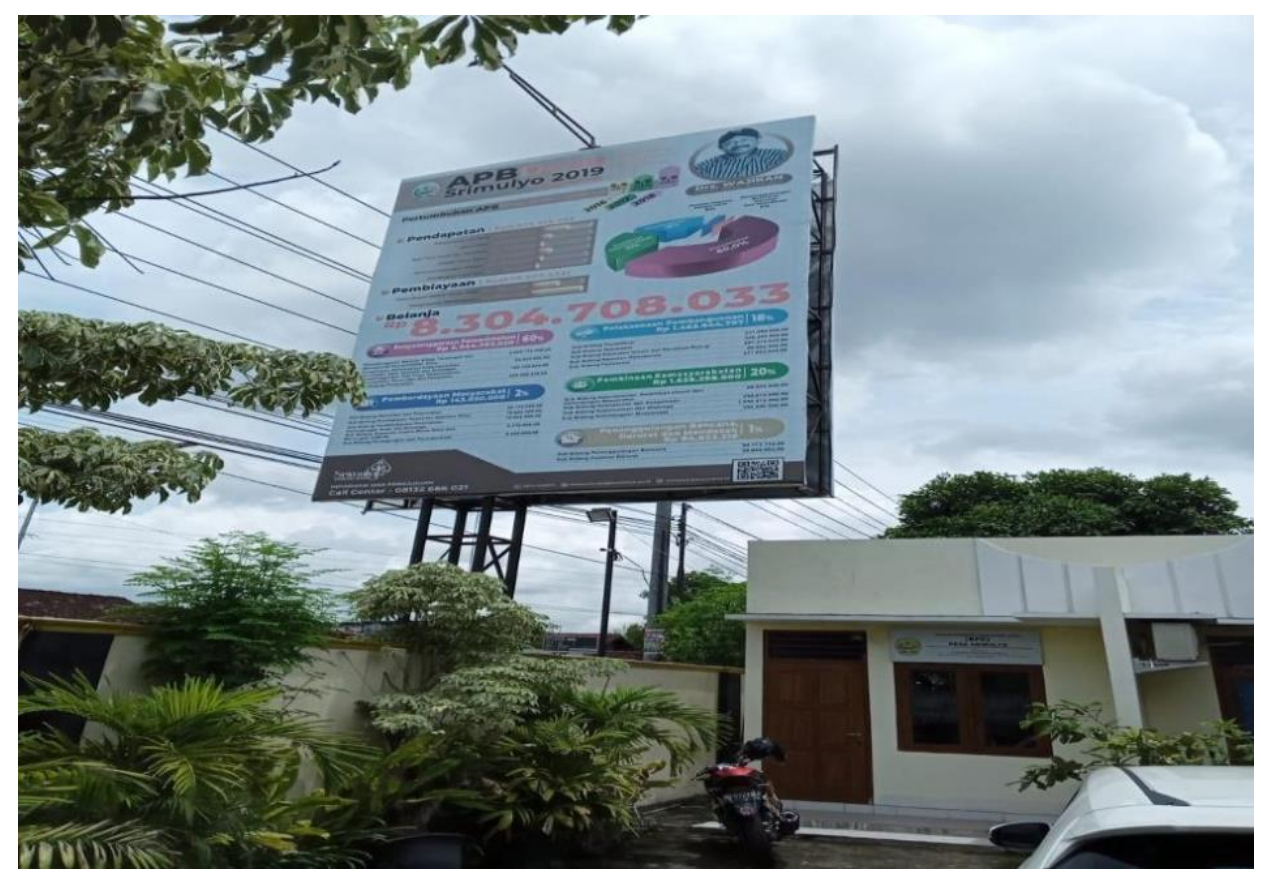

Sumber: Dokumentasi hasil penelitian dan observasi, 2019

Informasi kepada masyarakat sudah dibuka seluas-luasnya bahkan juga disediakan eSAMBAT berupa aplikasi yang dibuat untuk memudahkan warga masyarakat Desa Srimulyo untuk menyampaikan keluhan, saran, dan kritik dalam rangka membangun Srimulyo yang lebih baik.

\section{E. Terpenuhinya pengelolaan keuangan desa yang bisa dipertanggung- jawabkan}

Setiap tindakan atau kinerja pemerintah/lembaga pemerintah dalam mengelola keuangan desa harus dapat dipertanggungjawabkan kepada pihak- pihak yang memiliki hak atau berkewenangan untuk meminta keterangan akan pertanggungjawaban. laporan pengelolaan keuangan Desa Srimulyo sudah dibuat secara rutin setiap bulan. Dengan aplikasi siskeudes maka pengadministrasian keuangan desa menjadi lebih praktis, karena ketika semua transaksi sudah dientri ke dalam Siskeudes maka berbagai macam jenis laporan sudah jadi secara otomatis. Laporan pertanggungjawaban pengelolaan keuangan desa juga sudah disampaikan kepada Bupati melalui Camat selaku pihak pemerintah diatasnya sebagai laporan. Adapun Badan Permusyawaratan Desa (BPD) selaku mitra kerja pemerintah desa hanya melakukan pengawasan terhadap kinerja Lurah saja serta melakukan evaluasi terhadap Laporan Penyelenggaraan Pemerintah Desa.

\section{Kesimpulan}

Implementasi pengelolaan keuangan Desa Srimulyo Kecamatan Piyungan telah berjalan dengan cukup baik, hal tersebut dapat dilihat dari: 
1. Pemerintah Desa Srimulyo sudah melaksanakan pengelolaan keuangan desa dengan transparan. Data terkait APBDesa dapat diakses diwebsite resmi desa https://srimulyo-bantul.desa.id dan juga di papan pengumuman yang ada di desa.

2. Proses Pengelolaan Desa Srimulyo juga bisa dipertanggungjawabkan dan ketika pihakpihak terkait yang berkepentingan untuk meminta informasi maka dapat diberikan data-datanya. Buku Kas Umum ditutup setiap akhir bulan. Buku Pembantu Kas Umum juga sudah dibuat terdiri dari Buku Pembantu Kas Tunai, Buku Pembantu Bank, Buku Pembantu Pajak, Buku Pembantu Panjar dan Laporan Realisasi Anggaran

3. Pengelolaan keuangan desa Desa Srimulyo sudah mengikutsertakan keterlibatan masyarakat baik secara langsung maupun tidak langsung melalui lembaga perwakilan yang dapat menyalurkan aspirasinya dalam hal ini Badan Permusyawaratan Desa.

4. Pengelolaan anggaran di Desa Srimulyo sesuai dengan peraturan perundangundangan yang berlaku. Lurah Desa sudah menyusun Peraturan Desa tentang APBDesa Tahun 2019 dan Peraturan Desa tentang Penjabaran APBDesa Tahun 2019 yang menjadi dasar pengelolaan keuangan desa dalam masa 1 (satu) tahun anggaran, dan sudah sesuai dengan tahapannya, yakni: perencanaan, pelaksanaan, penatausahaan, pelaporan dan pertanggungjawaban.

Akan tetapi berdasarkan analisis data dan pembahasan yang sudah dilakukan maka rekomendasi dan saran yang bisa disampaikan adalah sebagai berikut:

1. Perlunya pendampingan dalam pengisian Siskeudes dari pemerintah Kabupaten Bantul;

2. Perlunya penyempurnaan aplikasi Siskeudes agar tidak terjadi upload data yang sudah masuk menjadi hilang dan laporan konsolidasi juga bisa dipergunakan, serta agar aplikasi Siskeudes bisa diakses dari mana saja.

\section{Daftar Pustaka}

Haerul, Akib, H., \& Hamdan. 2016. Implementasi Kebijakan Program Makassar Tidak Rantasa di Kota Makassar . Jurnal Administrasi Publik, 6(2), 21-34. Retrieved from http://ojs.unm.ac.id/index.php/iap/article/view/2477/1272

Islamy, I. 2010. Prinsip-Prinsip Perumusan Kebijakan Negara. Jakarta: Bumi Aksara.

Moleong, Lexi J. 2012. Metodologi Penelitian Kualitatif Edisi Revisi. Bandung: PT Remaja Rosdakarya.

Pülzl, H., \& Treib, O. 2007. Implementing Public Policy. In F. Fi scher, G. J.

Miller, \& M. S. Sidney, Handbook of Public Policy Analysis Theory, Politics, and Methods (pp. 89-107). New York: CRC Press Taylor \& Francis Group.

Ramdhani, M. A., \& Ramdhani, A. 2017. Konsep Umum Kebijakan Publik. Jurnal Publik, Vol. 11 No. 01.

Subarsono, A. G. 2011. Kebijakan Publik: Konsep, Teori, dan Aplikasi. Jogyakarta: Pustaka Pelajar. 
Wahab, S. A. 2010. Pengantar Analisis Implementasi Kebijakan Negara. Jakarta: Rineka Cipta.

\section{Perundang-Undangan}

Undang-Undang Nomor 6 Tahun 2014 tentang Desa

Peraturan Menteri Dalam Negeri Republik Indonesia Nomor 20 Tahun 2018 tentang Pengelolaan Keuangan Desa

Peraturan Bupati Bantul Nomor 82 Tahun 2019 tentang Pengelolaan Keuangan Desa.

\section{Website}

https://srimulyo-bantul.desa.id

http://www.bpkp.go.id/diy.bpk 